\title{
The Use of Pepaccur Local Wisdom for Indonesian Literary Teaching Materials
}

\author{
Muhammad Fuad ${ }^{1 *}$, Anwar Efendi ${ }^{2}$, Ulul Azmi Muhammad ${ }^{3}$ \\ ${ }^{1}$ Lampung State University, Lampung, Indonesia \\ ${ }^{2}$ Yogyakarta State University, Yogyakarta, Indonesia \\ ${ }^{3}$ Program of History Education, Sebelas Maret University, Surakarta, Indonesia \\ e-mail: abuazisah59@yahoo.co.id, anwar@uny.ac.id, sparta95@student.uns.ac.id
}

\begin{abstract}
The cultural diversity that exists in various regions in Indonesia produces a lot of potential for local wisdom and tradition. Various Indonesian local wisdom has been used as teaching material in the classroom. However, pepaccur local wisdom is still rarely known and used as teaching material. Therefore it is a novelty to turn pepaccur local wisdom into Indonesian literary teaching materials. This study aims to investigate the properness of pepaccur local wisdom for Indonesian literary teaching materials. The qualitative approach used in this study is characterized by collecting data through interviews, observation, recording and book review, and other sources related to pepaccur local wisdom. Content analyses were also used in analyzing the collected data. The results of this study are in the form of pepaccur presentations that are appropriate to be used as teaching materials for Indonesia language and literature based on the characteristics of the functions and values of local wisdom contained in them. Values contained in pepaccur such as religion, simplicity, cooperation, and politeness can be a reference in behaving in the community and this integration can be an effort to preserve local wisdom that has begun to be abandoned by the Lampung community. Implications from this study, through pepaccur-based teaching materials, students can learn to live a simple life, have a community with mutual help and respect, and learn poetic arts to provide entertainment and advice.
\end{abstract}

Keywords: Pepaccur; Local Wisdom; Teaching Material; Literature Learning; Junior High School Students

\section{Introduction}

The cultural diversity that exists in various regions in Indonesia produces a lot of potential for local wisdom and tradition. Historical investigation shows that the local culture is passed on to the younger generation regarding beliefs, systems of government, health, and the lineage system (Meliono, 2011) Local knowledge in some regions of Indonesia can be described as relating to beliefs and customs (Yuliana et al., 2017). The diversity of culture, tradition, and local wisdom becomes an identity that should be maintained and preserved especially by and for local people (Nasrudin et al., 2018). However, cultural wealth is applied only to the older generation. Meanwhile, the lack of attention of young people in protecting culture, traditions, and local wisdom as such can have an impact on the loss of cultural wealth as a characteristic of a region.

Regarding the main points stated above, education is the right media to prepare younger generations who have creative minds, wisdom, openness, and constructive attitudes. Indonesian education needs to include the value of pluralism and multiculturalism or is builtin line with the reality of diverse cultures so that it can contribute to the formation of important values in the development of cultural awareness. It means that there is a need to form a curriculum that places cultural paradigms in the context of national education such as integrating local wisdom. In this case, the integration of local wisdom in the learning process in schools needs to be done as part of efforts to preserve local wisdom (Nasrudin et al., 2018). It is an effort to increase student interest (Shidiq, 2016), attitudes (Permatasari \& Hakam, 2018; Suastra et al., 2017), personality traits (Permatasari \& Hakam, 2018; Suastra et al., 2017), and national identity (Khoeriyah et al., 2018). Learning by incorporating local wisdom

\footnotetext{
* Corresponding author.

Received 30 December 2019; Accepted 5 June 2020; Available online 20 June 2020

(C) 2020 JPI. All Rights Reserved
} 
becomes a means for students to create meaningful learning because it relates to concrete situations faced.

In line with this, there is an oral tradition of reading pepaccur in the community of Lampung Pepadun. Pepaccur is oral literature in the form of poetry commonly used to advise the ceremony of giving customary titles. Many of the values contained in Pepaccur are used as a reference for students in reflecting attitudes and behaviors in the community. Unfortunately, in practice, there are only older generations who are competent (Sukmawati, Fuad, \& Munaris, 2014). Therefore, making pepaccur as a learning material becomes an opportunity to instill cultural values to the younger generation.

Exploring local wisdom to be applied as a learning context can be an important part of developing student characteristics (Yuliana et al., 2017). Several studies have been carried out on the application of local wisdom as a source of learning, such as the local wisdom of the indigenous people of Lekuk 50 Tumbi as a source of biological learning (D. C. Putri, Munandar, \& Supriatno, 2019), the development of multimedia modules based on local wisdom in physics learning (Delima, Warsono, Supahar, \& Jumadi, 2018), South Kalimantan's local wisdom as a source of physics learning (Hartini, Firdausi, Misbah, \& Sulaeman, 2018), the application of Bali's local wisdom-based learning model to mathematics learning (Parwati, Sudiarta, Mariawan, \& Widiana, 2018), and the independent electricity village local wisdom as a source of science learning (Basuki, Jufrida, \& Suryanti, 2019). However, the application of local wisdom as a source of learning in previous studies was more dominantly related to science subjects. Researches that incorporate local wisdom into Indonesian literary studies are still rarely conducted. In addition, pepaccur local wisdom has not been widely used as a learning material. Therefore, research on the development of Indonesian literary teaching materials based on local wisdom pepaccur becomes important to do and becomes a novelty in research.

This research focuses on integrating the local wisdom of pepaccur in Indonesian literary teaching materials. The present study aimed to investigate the properness of pepaccur local wisdom for Indonesian literary teaching materials. In light of this purpose, it was attempted to determine the characteristics of pepaccur, the cultural values contained in pepaccur, and the way pepaccur was integrated into Indonesian literary teaching material. The positive impact of the implementation of this pepaccur-based language and literature learning process is the preservation of local wisdom and the values contained in it to the younger generation. In addition, this research is also expected to be a reference for teachers and policymakers to integrate local wisdom in learning.

\section{Method}

The qualitative approach with a descriptive model was used in this study. The description method through a qualitative approach is used to describe the object of research systematically, accurately, and factually. After describing the object or focus of research, researchers describe learning in junior high school and look for the relationship between the object under study with literary learning in junior high school. This research uses a purposive sampling technique. The sample used was the people in North Lampung Regency especially the Lampung Abung community which consisted of traditional leaders (pepadun), and community leaders.

The research data consisted of pepaccurstructure, pepaccurfunction, type of pepaccur, cultural values contained in pepaccur, and the feasibility of pepaccur as teaching material. The data was collected using observations, records, making field notes, and interviews. Descriptive data analysis techniques were used in this study. Some of the steps taken are domain analysis, taxonomic analysis, componential analysis, and cultural theme analysis. The analysis is done by collecting and analyzing the contents of the pepaccur text.

\section{Results and Discussion}

\subsection{The Structure of Pepaccur of Lampung Pepadun Community}

Pepaccur local wisdom as one of the oral literature in the form of regional poetry and cultural results that are rich in meaning should be studied and introduced to all circles. On the other hand, there are elements in the poem which include the choice of words, sounds, stops, 
images, and language styles (Wolosky, 2001). Based on these elements, the structure of the pepaccur can be analyzed from the aspects of rhyme, rhythm, tone, structure, diction, and language style analyzed to make it easier for someone to recognize this art. In Table 1 below, we can see a description of the structure variable of pepaccur.

Table 1. Description of Pepaccur Structure

\begin{tabular}{|c|c|c|}
\hline Variable & Characteristics & Example of Pepaccur Text \\
\hline Rhyme & $\begin{array}{l}\text { The same sound repetition to form a } \\
\text { musicality. In general, pepaccur has } \\
\text { an abcabc and abab rhyme. }\end{array}$ & $\begin{array}{l}\text { Pepaccur rhythm abcabc } \\
\text { Sesikun ulun ghebei } \\
\text { Lagei lak ketinggalan } \\
\text { Tigeh di jaman tano Anggeulah ilmeu } \\
\text { paghei } \\
\text { Semungguk wat isseian Cemungak tando } \\
\text { hapo }\end{array}$ \\
\hline Rhythm & $\begin{array}{l}\text { The function of rhythm is to make the } \\
\text { poem sound melodious and easy to } \\
\text { read and to create charm. }\end{array}$ & $\begin{array}{l}\text { The rhythm of using the letter "o" in each } \\
\text { row } \\
\text { Dang aso badan gham lagi kuat } \\
\text { Supo mak makko tujeu pak ghabai } \\
\text { Mak ngehabo katteu mak kawer tubat } \\
\text { Tibo-tibo panggilan sapppai }\end{array}$ \\
\hline $\begin{array}{l}\text { Tone and } \\
\text { atmosphere }\end{array}$ & $\begin{array}{l}\text { Tones are related to the poet's } \\
\text { attitude, while the atmosphere is a } \\
\text { psychological result }\end{array}$ & $\begin{array}{l}\text { Tones advise with an atmosphere of } \\
\text { gratitude } \\
\text { Syukur alhamdulillah } \\
\text { Tigeh judeumeu tano Dendeng segalo } \\
\text { badan Kekalau metei wo tuah Ino sai upo } \\
\text { duo } \\
\text { Kiluai adek tuhan }\end{array}$ \\
\hline Structure & $\begin{array}{l}\text { The pepaccur structure consists of } \\
\text { opening, content, and closing }\end{array}$ & $\begin{array}{l}\text { Opening verse } \\
\text { Tano nikeu kak diulun Rubah bebasing } \\
\text { tinggo } \\
\text { Dang geggeh sangun lagei } \\
\text { Bahaso sopan santun } \\
\text { Ramah puppik penyawo } \\
\text { Jamo ahli pamili } \\
\text { Content verse } \\
\text { Jamo gham jao ulun } \\
\text { Dang kurang wawwah pudak } \\
\text { Tutuk munih perhatei } \\
\text { Nuo ditahen buyun } \\
\text { Ramah jamo serundo } \\
\text { Tetangga kanan kirei } \\
\text { Closing verse } \\
\text { Pepaccur gelek dijo } \\
\text { Mahhappun pusinei pai } \\
\text { Sai salah dang dicattik } \\
\text { Ilmu lakwat pigho } \\
\text { Anggep sikam betawai } \\
\text { Rasan gham jimo lunik }\end{array}$ \\
\hline Diction & $\begin{array}{l}\text { Diction in pepaccur functions to } \\
\text { highlight the foregrounding of work } \\
\text { in the form of figures, settings, and } \\
\text { circumstances }\end{array}$ & $\begin{array}{l}\text { Diction related to the union of relations } \\
\text { between men and women (marriage) } \\
\text { Syukur Alhamdulilah }\end{array}$ \\
\hline
\end{tabular}




\begin{tabular}{lll}
\hline \multicolumn{1}{c}{ Variable } & \multicolumn{1}{c}{ Characteristics } & \multicolumn{1}{c}{ Example of Pepaccur Text } \\
\hline $\begin{array}{l}\text { Language } \\
\text { style }\end{array}$ & $\begin{array}{l}\text { The language styles of pepaccur } \\
\text { are allegory and personification } \\
\text { Lapah subuk metei wo } \\
\text { dang nginan watteu perleu }\end{array}$ & $\begin{array}{l}\text { Personification language style } \\
\text { Dinggak denio ghadeu keliwat } \\
\end{array}$ \\
& Layen jugo sai, sai guai halai \\
& Kuharep mettei dang pai tesemat \\
& Ingk pelayue dijimmeh sawwai \\
\hline
\end{tabular}

\subsection{Pepaccur Cultural Values}

Pepaccur contains cultural values that can shape one's personality is a good direction if studied and applied in social life. The values contained in the pepaccur include religious and moral values (independence, cooperation, and manners). The pepaccur texts that contain these values can be seen in Table 2 .

Table 2. Pepaccur Cultural Values

\begin{tabular}{|c|c|c|}
\hline Value & Pepaccur Text & Text Philosophy \\
\hline Religious & $\begin{array}{l}\text { Suwo pungen tengadah } \\
\text { Kilui appun duso } \\
\text { Serto selamat badan } \\
\text { Najin mak dapek kiwah }\end{array}$ & $\begin{array}{l}\text { The religious activity in the form of } \\
\text { prayer is done to ask for forgiveness of } \\
\text { sins and the salvation of life in the world } \\
\text { and hereafter. }\end{array}$ \\
\hline Simplicity & $\begin{array}{l}\text { Cukuplah sederhano } \\
\text { Asal mak kekurangan }\end{array}$ & $\begin{array}{l}\text { The meaning contained in the text is a } \\
\text { simple life without lacking anything in } \\
\text { living life. }\end{array}$ \\
\hline $\begin{array}{l}\text { Mutual } \\
\text { cooperation }\end{array}$ & $\begin{array}{l}\text { Jamo Lah- Uyang dang makko lalat } \\
\text { Pilih pikiran kidapek ngesai } \\
\text { Bebasing rasan jejamo ngakkat } \\
\text { Walau yo biyak mak ghaso palai }\end{array}$ & $\begin{array}{l}\text { Life is helping each other, applied to } \\
\text { brothers and neighbors. }\end{array}$ \\
\hline Politeness & $\begin{array}{l}\text { Sebagai tando gham ngemik adat } \\
\text { Pill sengirei musti dipakai } \\
\text { Nengah nyappur sino dang telat } \\
\text { Nemui nyimah lajeu disakai }\end{array}$ & $\begin{array}{l}\text { Manners in society are shown through } \\
\text { the behavior of serving guests well, } \\
\text { mutual respect, and mutual assistance. }\end{array}$ \\
\hline
\end{tabular}

In Table 2, the values contained in pepaccur are religious, simplicity, cooperation, and courtesy. When the above pepaccur is analyzed more deeply, it turns out to have full of values that can be a reference in socializing. The results of the study revealed that attitudes and values in a person can grow through several ways such as using cultural literacy in learning (Taylor, 2015), giving instructions so that students are aware of their responsibility (Eacott, 2012), and involving them with direct practice in the community (Juriza et al., 2011).

\subsection{Pepaccur Integration in Language and Literature Learning Materials}

The currently growing culture is degraded and tends to leave behind local wisdom because the social order beginning to change and not wise treatment towards the advancement of technology, as well as the growing knowledge. Exploring local wisdom in the school environment is needed to overcome these problems (Hartadiyati, Rizqiyah, Wiyanto, Rusilowati, \& Prasetia, 2017). On the other hand, the teacher has a responsibility in preparing the learning context that directs the students' mindset to shape the situation and environment that supports their identity. In this case, the teacher can provide a variety of learning processes that are not only sourced from textbooks in the school (Pornpimon, Wallapha, \& Prayuth, 2014) but can also be from things that are around the social environment. 
The product of integrating pepaccur local wisdom in language and literature learning, in addition to teaching materials, is the lesson plan (RPP). A lesson plan is made by paying attention to the syntax of the learning method that matches the material characteristics of the poem. The learning method used is problem solving with the scientific approach. In Table 3, we can see the problem-solving learning syntax in pepaccur poetry material. One of Pepaccur's integration in literary teaching materials is shown in Figure 1. The students were asked to analyze rhymes, rhythms, verses, and the values contained in the pepaccur texts.

\begin{tabular}{|c|c|}
\hline \\
\hline \\
\hline \multicolumn{2}{|l|}{$\begin{array}{l}\text { Bacalah teks pepaccur berikut! } \\
\text { Agamo dang sapppai lalai } \\
\text { Lakunei perittah Tuhan }\end{array}$} \\
\hline \multirow{2}{*}{\multicolumn{2}{|c|}{$\begin{array}{l}\text { Jawehei sai mak beguno } \\
\text { Adat munih tepakai }\end{array}$}} \\
\hline & Adat perlu dijunjung \\
\hline \multirow{2}{*}{\multicolumn{2}{|c|}{$\begin{array}{l}\text { Mufakat, sakai sambayan } \\
\text { Nengah nyimah dang lupo }\end{array}$}} \\
\hline & \\
\hline \multirow{6}{*}{$\begin{array}{l}\text { Siwo pungen tengadah } \\
\text { Kilui appun duso } \\
\text { Serto selamat badan } \\
\text { Najin mak dapek kiwah } \\
\text { Cukuplah sederhano } \\
\text { Asal mak kekurangan } \\
\text { Sebagai tando gham ngemik adat } \\
\text { Pill sengirei musti dipakai } \\
\text { Nengah nyappur sino dang telat } \\
\text { Nemui nyimah lajeu disakai } \\
\\
\text { Sembahyang dang sappai lalai } \\
\text { Tanda ingok di Tuhan } \\
\text { Mak pandai gham kilu tawai } \\
\text { Mangi dang salah jalan } \\
\text { Dang mak nemen bekerjo } \\
\text { Dang besai inei iteu } \\
\text { Disiplin utamoko } \\
\text { Dang lalai jamo watteu } \\
\text { Pertamo, beribadah } \\
\text { Sembayang wakteu limo } \\
\text { Dang sappai ketinggalan } \\
\text { Kiri munih Fatihah } \\
\text { Tehadep sai kak meno } \\
\text { Kapak sai lagei tengan }\end{array}$} & Sambil tangan tengadah \\
\hline & Mohon ampun dosa \\
\hline & Serta mohon keselamatan \\
\hline & Meskipun tidak bisa mewah \\
\hline & Cukuplah sederhana \\
\hline & Asalkan tidak kekurangan \\
\hline \multirow{5}{*}{$\begin{array}{l}\text { Sebagai tando gham ngemik adat } \\
\text { Pill sengirei musti dipakai } \\
\text { Nengah nyappur sino dang telat } \\
\text { Nemui nyimah lajeu disakai }\end{array}$} & Sebagai tanda kita mempunyai adat \\
\hline & Junjung tinggi harga diri (Pill \\
\hline & pesengiri) \\
\hline & $\begin{array}{l}\text { Bergaul ditengah masyarakat, jangan } \\
\text { lupa }\end{array}$ \\
\hline & $\begin{array}{l}\text { Layani tamu dengan baik, hormati } \\
\text { dan saling membantu sesama }\end{array}$ \\
\hline \multirow{4}{*}{$\begin{array}{l}\text { Sembahyang dang sappai lalai } \\
\text { Tanda ingok di Tuhan } \\
\text { Mak pandai gham kilu tawai } \\
\text { Mangi dang salah jalan }\end{array}$} & Jangan melalaikan salat \\
\hline & Tanda ingat kepada Tuhan \\
\hline & Jika tak tahu, minta nasssihat \\
\hline & Supaya jangan salah jalan \\
\hline \multirow{4}{*}{$\begin{array}{l}\text { Dang mak nemen bekerjo } \\
\text { Dang besai inei iteu } \\
\text { Disiplin utamoko } \\
\text { Dang lalai jamo watteu }\end{array}$} & Bekerjalah yang tekun \\
\hline & Janganlah banyak tingkah \\
\hline & Disiplin utamakan \\
\hline & Jangan menyia-nyiakan waktu \\
\hline Pertamo, beribadah & Pertama, beribadah \\
\hline Sembayang wakteu limo & Sembayang lima waktu \\
\hline \multirow{2}{*}{$\begin{array}{l}\text { Dang sappai ketinggalan } \\
\text { Kiri munih Fatihah }\end{array}$} & Jangan sampai ditinggalkan \\
\hline & Kinim pula fatihah \\
\hline \multirow{2}{*}{$\begin{array}{l}\text { Tehadep sai kak meno } \\
\text { Kapak sai lagei tengan }\end{array}$} & Untuk yang telah meninggal \\
\hline & Maupun yang masih hidup \\
\hline
\end{tabular}

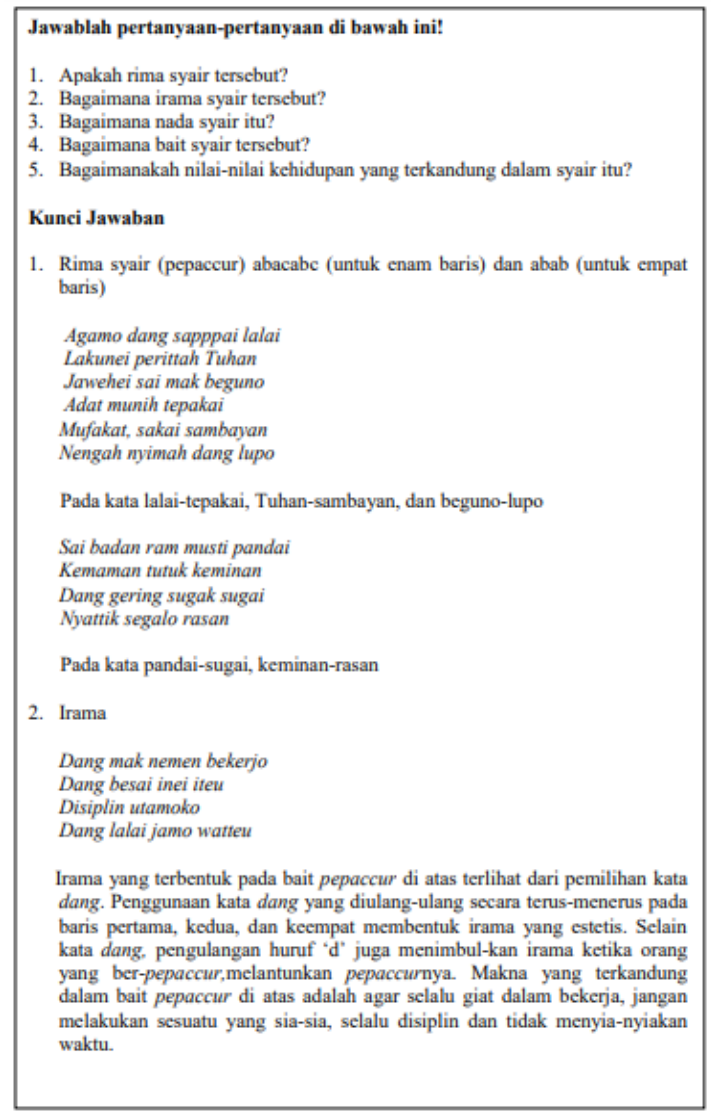

Figure 1. Pepaccur text in literature learning material

Table 3. Syntax of Problem-Solving Learning in Pepaccur Material

\begin{tabular}{|c|c|c|c|}
\hline Activities & Scientific approach & Learning Syntax & Activity Description \\
\hline \multirow[t]{4}{*}{ Preliminary } & Observing & & Apperception \\
\hline & Asking & & Drawing students' attention \\
\hline & Asking & & Motivating \\
\hline & Observing & & Providing reference \\
\hline \multirow[t]{4}{*}{ Simplicity } & $\begin{array}{l}\text { Observing } \\
\text { Asking }\end{array}$ & $\begin{array}{l}\text { Stage 1: Orientation to } \\
\text { the problem }\end{array}$ & $\begin{array}{l}\text { The teacher explains that } \\
\text { Pepaccur is a type of local } \\
\text { poetry. }\end{array}$ \\
\hline & $\begin{array}{l}\text { Observing } \\
\text { Asking }\end{array}$ & $\begin{array}{l}\text { Stage 2: Learning } \\
\text { organization }\end{array}$ & $\begin{array}{l}\text { The students are introduced to } \\
\text { the example of the pepaccur } \\
\text { text. }\end{array}$ \\
\hline & Trying & $\begin{array}{l}\text { Stage 3: Group } \\
\text { investigation }\end{array}$ & $\begin{array}{l}\text { In the divided groups, the } \\
\text { students work together to } \\
\text { analyze the elements of } \\
\text { Pepaccur. }\end{array}$ \\
\hline & $\begin{array}{l}\text { Reasoning } \\
\text { Communicating }\end{array}$ & $\begin{array}{l}\text { Stage } 4 \text { : Development } \\
\text { and presentation of } \\
\text { problem-solving } \\
\text { results }\end{array}$ & $\begin{array}{l}\text { After the students analyze } \\
\text { pepaccur, the teacher asks the } \\
\text { group to present the results of } \\
\text { the discussion. }\end{array}$ \\
\hline
\end{tabular}




\begin{tabular}{|c|c|c|c|}
\hline Activities & Scientific approach & Learning Syntax & Activity Description \\
\hline \multirow{4}{*}{ Closing } & Communicating & $\begin{array}{l}\text { Stage 5: Analysis and } \\
\text { evaluation of the } \\
\text { problem-solving } \\
\text { results }\end{array}$ & $\begin{array}{l}\text { The teacher confirms the results } \\
\text { of the discussion and the } \\
\text { students' answers so that they } \\
\text { can revise the results of their } \\
\text { work }\end{array}$ \\
\hline & Reasoning & Reviewing & $\begin{array}{l}\text { The teacher asks several } \\
\text { questions that lead to material } \\
\text { conclusions. }\end{array}$ \\
\hline & $\begin{array}{l}\text { Reasoning } \\
\text { Communicating }\end{array}$ & Evaluating & $\begin{array}{l}\text { The students individually work } \\
\text { on problems related to the } \\
\text { elements of pepaccur }\end{array}$ \\
\hline & Communicating & Reflection & $\begin{array}{l}\text { The teachers and student } \\
\text { reflection on learning. }\end{array}$ \\
\hline
\end{tabular}

\subsection{Discussion}

The Lampung Pepadun community is one of the communities in Indonesia which has a unique language and cultural tradition, namely oral literature, Pepaccur. Preservation of oral literature is important to do because given the current fact that pepaccur users are only limited to the older generation. The young generation needs to learn pepaccur so that this literary art can be preserved and not lost eroded by time. The introduction of pepaccur characteristics and cultural values can be done by integrating pepaccur in school learning.

The dialect $\mathrm{O}$ in pepaccur, which is a cultural product of the Lampung Pepadun people, has distinctive elements with a specific purpose of use, namely as a traditional custom in giving titles by community leaders to their people who have stepped on adulthood and marriage age. In Table 1 there are examples of the structure of pepaccur, namely rhyme, rhythm, tone and atmosphere, framework, diction, and language style. Rhyme is the same sound repetition to form musicality (Baker, 2016; Fabb, 2017). Rhyme in pepaccur shows the same sound repetition for each stanza. In one stanza pepaccur consists of six rows or four rows, in the rows, there are several repetitions of the same sound to make musicality. Rhyme in pepaccur is a word game that has a beauty effect. The form of the rhyme is the end of rhyme and the internal rhyme. This rhyme not only puts forward artistic sound but also promotes it through words that are well-chosen by poets.

The rhythm that is formed in the pepaccurfunctions so that the poem sounds melodious, easy to read, causes an unbroken and concentrated flow of feelings or thoughts that give rise to clear and vivid images, and create magical charm or power. In Table 1, the rhythm used by poets has a distinctive characteristic, which is to use the letter "o" in each line this shows that pepaccur comes from the community of Lampung Pepadun with "o" dialect. Through tones, the poet can convey the desired attitude to the reader, whether he wants to be patronizing, advising, mocking, insinuating, or just telling the reader something. Whereas, the atmosphere is a psychological result arising from poetry on the reader. For example, the sorrow that the poet creates an atmosphere of compassion in the reader. Religious tones create a solemn atmosphere. Tones in pepaccur are manifestations of emotions or overflowing feelings of people who do pepaccur that they want to convey to readers. The tone in pepaccur describes the attitude of advising people who do pepaccur in the form of religious tones and happy atmosphere

The pepaccur framework is part of the lines that make up the temple. The pepaccur framework consists of opening, filling, and closing. The function of the pepaccur framework is to make it easier for listeners to understand pepaccur. The choice of words in pepaccur is used appropriately with ideas to represent the thoughts and feelings to be conveyed to others and expressed in a sentence pattern both verbally and in writing to give rise to a function or effect for the reader. The choice of words or diction related to giving advice will be given. Dictation in pepaccur functions to (1) highlight certain parts or foregrounding of work, this form of prominence can be in the form of figures, settings, and circumstances in a literary work, (2) clarify the intentions and turn on sentences, (3) create beauty in terms of forms as created by the speaker, (4) creating a religious impression, and (5) displaying a picture of the atmosphere. 
The language style is a typical way of expressing thoughts and feelings in written or oral form. In poetry, poets try to convey ideas, feelings, and thoughts using language that is made in such a way that it looks beautiful and full of meaning. The type of language style used in pepaccur is the style of allegory and personification. The function of the style of language in pepaccur is to give effect to certain meanings and intentions.

Pepaccur structure which consists of several elements can be a reference for students in learning and getting to know elements of literature as well as local culture such as in learning biology that inserts local wisdom of indigenous peoples Curves 50 Tumbi in managing agricultural land (Putri et al., 2019). The element of Curves 50 concerning the environment and natural surroundings becomes guidance of the life. New information from local wisdom can be a new additional teaching material in the learning.

Globalization changes the social order that has taken root in the community. Correspondingly, changes in values and culture that exist in the community are facts that cannot be denied. Indonesian society that is synonymous with wisdom, friendliness, courtesy, democracy, and social consensus, shows a trend that is gradually being transformed into instant and pragmatic. What's more, the original digital generation has used technology and global products. They gradually leave the noble values of Indonesian culture (Anggraini \& Kusniarti, 2017). Basic values are core concepts that combine cognitive and affective elements. These elements are influenced by the socio-cultural environment, which can cause individuals to differ in the way they manifest each value in the community. Cultural groups develop cognitions, emotions, and tendencies from their beliefs about the world and life to form existential propositions. Value orientation or worldview is considered as a system or culture-specific perspective to understand the world (Yeh, Carter, \& Pieterse, 2004). In pepaccur, the values contained can illustrate the views of Lampung people at that time on the social life of the community such as religion, simplicity, cooperation, and courtesy.

Cultural values are proven through various studies to be able to avoid the public from the negative influence of globalization (Schiefer, Mollering, Daniel, Benish-weisman, \& Boehnke, 2010), maintain community morals (Vauclair \& Fischer, 2011), and become important variables in the career development process (Brown, 2002; Hartung, 2002). Therefore, indigenous cultural values that exist in the community must be preserved. One way that can be done so that the values contained in pepaccur can be preserved is by integrating pepaccur local wisdom into learning. Through pepaccur's local wisdom teaching, the values contained in it can be inherited to the younger generation.

In pepaccur implementation, local wisdom will direct the application of cultural values in students' behaviors effectively (Mujiyati, Warto, \& Sutimin, 2017). Apart from the family environment and the surrounding community, integrating pepaccur in formal learning in the school environment can add to the students' skills in doing pepaccur so that this local wisdom can be maintained by the younger generation. The values and norms of local wisdom integrated into the learning process also function in preparing students in the millennial era (Yufiarti, Rivai, \& Pratiwi, 2018).

One of the basic competencies in learning literature at the junior high school level is analyzing the elements of poetry the students listen to. Poetry in this context can be replaced with the poetry of local wisdom from Lampung, namely pepaccur. In addition to analyzing pepaccur elements, students can also learn the culture in which they live so that learning takes place more meaningfully. Meaningful learning occurs when learning has relevance to things that have been known by students so that they can be actively involved in making meaning and concluding the context they are learning (Kean \& Kwe, 2014). The positive impact of learning this pepaccur is that students unconsciously instill religious character values, simplicity, cooperation, and manners in themselves. This is in line with the research on the forerunner of local wisdom based character education applied in early childhood education (Ernawati, Siswoyo, Hardyanto, \& Raharjo, 2018) that has been integrated into the school's teaching plan so that characters are formed in their daily activities.

Education is a conscious and planned effort to encourage the development and potential of students to be able to benefit their lives both as individuals and as members of society. Education is included in one form of human culture, because it is always dynamic, following 
the acceleration of the rate of change and the dynamics of the culture of society. Through education, it is hoped that the basic values, thoughts, and morality of the nation can be instilled to be able to produce a generation that is strong in faith, personality, rich in intelligence, and superior in mastering technology and information. For this reason, we need education based on local wisdom (Darmadi, 2018).

Table 3 shows the combination of the demands of education in the era of globalization by maintaining local wisdom. The use of the problem-based learning method in learning can raise problems about the fewer Lampung people who do pepaccur. This is a major problem that will be discussed in the learning process. By using the context of the issue, and making the pepaccur text as literary learning material, then pepaccur local wisdom will be known by students. Students give positive responses when learning literature about the elements of pepaccur. They seemed enthusiastic in following the lesson and actively played their respective roles in the discussion group. At the end of the meeting students have notes on the discussion about pepaccur so that they are easy to summarize and understand the topic. Group discussion activities in exploring pepaccur can stimulate effective and meaningful learning for students because they are proud of their everyday culture as part of the learning material at school. The integration of local wisdom in education can encourage students to love literary works that are very close to the neighborhood (Sutrimah, Winarni, Wardani, \& Ngadiso, 2019).

The integration of local wisdom has been carried out in various regions in Indonesia (Atmojo, 2015; Khoeriyah, Warto, \& Sariyatun, 2018b). In addition to the culture of pepaccur, other local wisdom that has been integrated into learning also varies, such as folklore Sayu Wiwit (Fatimah, Sulistyo, \& Saddhono, 2017), Ammatoa Kajang Tribe (Surtikanti, Syulasmi, \& Ramdhani, 2017), karawitan art (Udin, Zuber, \& Demartoto, 2018), the local wisdom of the Sitiwinangun Cirebon area (D. P. Putri, 2018), local wisdom in Bali (Mustika, 2018), local wisdom of the Javanese and Sundanese people (Maruapey, 2016; Permatasari \& Hakam, 2018) and various other uses of Indonesian local wisdom (Basuki et al., 2019; Darmadi, 2018; Hartadiyati et al., 2017; Setiawan, Innatesari, Sabtiawan, \& Sudarmin, 2017; Sunjaya \& Fatimah, 2017; Vitasurya, 2016).

A large number of integration of local wisdom in various regions in Indonesia is evidence of Indonesia's cultural richness. Integrating pepaccur into Indonesian literary teaching materials adds to the list of local wisdom that has been preserved through teaching materials. Pepaccur local wisdom is a novelty in this study. In addition, by integrating pepaccur into Indonesian literary teaching materials is expected to instill cultural values to the students.

\section{Conclusion}

Pepaccur is one of the local wisdom of the Lampung Pepadun community, which falls into the category of not yet or less getting the attention of the younger generation. The use of pepaccur by traditional leaders is generally carried out during a traditional ceremony of giving titles. Pepaccur has a rhyme structure, rhythm, tone, and atmosphere, framework, diction, and language style. Besides, pepaccur contains social values and norms that can be learned and instilled in social behaviors, such as religion, simplicity, cooperation, and courtesy. With this advantage, pepaccur is worthy of being used as teaching material for Indonesian literary lessons in school. In terms of achieving basic competencies regarding poetry, the teacher can prepare pepaccur texts for the teaching material whose structure and values contained therein can be analyzed. The integration products are teaching materials and lesson plans which can be continued to be used so that the tradition of doing pepaccur can be sustained.

\section{References}

Anggraini, P., \& Kusniarti, T. (2017). Character and Local Wisdom-Based Instructional Model of Bahasa Indonesia in Vocational High Schools. Journal of Education and Practice, 8(5), 23-29.

Atmojo, S. E. (2015). Learning Which Oriented on Local Wisdom to Grow A Positive Appreciation of Batik Jumputan (Ikat Celup Method). Jurnal Pendidikan IPA Indonesia, 4(1), 48-55. https://doi.org/10.15294/jpii.v4i1.3501 
Baker, J. (2016). 'Music is feeling, then, not sound': Rhyme in the Development of Wallace Stevens. The Cambridge Quarterly, 3(4). https://doi.org/10.1093/camqtly/bfw022

Basuki, F. R., Jufrida, \& Suryanti, K. (2019). Identification of potential local wisdom of senamat ulu village (electrical independent village) as a source of science learning. In Journal of Physics: Conference Series (pp. 1-9). IOP Publishing. https://doi.org/10.1088/17426596/1185/1/012102

Brown, D. (2002). The Role of Work and Cultural Values in Occupational Choice, Satisfaction, and Success: A Theoretical Statement. Journal of Counseling and Development, 80, 48-56.

Darmadi, H. (2018). Educational Management Based on Local Wisdom. Journal of Education, Teaching and Learning, 3(1), 135-145.

Delima, E., Warsono, Supahar, \& Jumadi. (2018). The importance of multimedia learning modules ( $\mathrm{mlms}$ ) based on local wisdom as an instructional media of 21 st century physics learning. In Journal of Physics: Conference Series (pp. 1-10). IOP Publishing.

Eacott, S. (2012). Introducing undergraduate students to school leadership concepts. Journal of Educational Administration, 50(2), 159-172. https://doi.org/10.1108/09578231211210521

Ernawati, T., Siswoyo, R. E., Hardyanto, W., \& Raharjo, T. J. (2018). Local-Wisdom-Based Character Education Management in Early Childhood Education. The Journal of Educational Development, 6(32), 348-355.

Fabb, N. (2017). Rhyme and alliteration. In What is Poetry? (Language and Memory in the Poems of the World).

Fatimah, F. N., Sulistyo, E. T., \& Saddhono, K. (2017). Local Wisdom Values in Sayu Wiwit Folklore As The Revitalization of Behavioral Education. Journal of Social and Islamic Culture, 25(1), 179-199. https://doi.org/10.19105/karsa.v25i1.1118

Hartadiyati, E., Rizqiyah, K., Wiyanto, Rusilowati, A., \& Prasetia, A. P. B. (2017). The Integrated Model of Sustainability Perspective in Spermatophyta Learning Based on Local Wisdom. Journal of Physics: Conference Series, 895(012051). https://doi.org/:10.1088/1742-6596/895/1/012051

Hartini, S., Firdausi, S., Misbah, \& Sulaeman, N. F. (2018). The Development of Physics Teaching Materials Based on Local Wisdom to Train Saraba Kawa Characters. Jurnal Pendidikan IPA Indonesia, 7(2), 130-137. https://doi.org/10.15294/jpii.v7i2.14249

Hartung, J. (2002). Cultural Context in Career Theory and Practice : Role Salience and Values Infusing Context Into Career Theory and Practice: The Career Development Quarterly, 51(September), 12-25.

Juriza, I., Ruzanna, Z., Harlina, H. S., Rohaizak, M., Zulkifli, Z., Fauzi, M. A., ... Lokman, S. (2011). Outdoor camps experiential learning activities for teamwork and leadership among medical students. Procedia - Social and Behavioral Sciences, 18, 622-625. https://doi.org/10.1016/j.sbspro.2011.05.091

Kean, A. C., \& Kwe, N. M. (2014). Meaningful Learning in the Teaching of Culture: The Project Based Learning Approach. Journal of Education and Training Studies, 2(2), 189-197. https://doi.org/10.11114/jets.v2i2.270

Khoeriyah, N., Warto, \& Sariyatun. (2018a). Learning history integrated local wisdom values " babad Banyumas " to build a student's national identity. In SHS Web of Conferences (Vol. 00091, pp. 1-6).

Khoeriyah, N., Warto, \& Sariyatun. (2018b). Learning history integrated local wisdom values "babad Banyumas" to build a student's national identity. SHS Web of Conferences, 42(00091), 1-6. https://doi.org/https://doi.org/10.1051/shsconf/20184200091

Maruapey, M. H. (2016). Contribution To Local Wisdom Leadership Of The National Policy On Java (Descriptive Study Against Election And Designation Of President Of The Republic Of Indonesia). International Journal of Scientific \& Technology Research, 5(06), 254258. Retrieved from www.ijstr.org

Meliono, I. (2011). Understanding the Nusantara Thought and Local Wisdom as an Aspect of the Indonesian Education. International Journal for Historical Studies, 2(2), 221-234.

Mujiyati, N., Warto, \& Sutimin, L. A. (2017). The Strategies to Improve Social Solidarity of 
Senior High School Students through. American International Journal of Social Science, 6(1), 65-70.

Mustika, I. K. (2018). Local Wisdom-Based Character Education In Teaching Balinese To Achieve National Integration Of a Nation. SHS Web of Conferences, 42(00013). https://doi.org/https://doi.org/10.1051/shsconf/20184200013

Nasrudin, D., Rochman, C., \& Muhyiddin, A. (2018). Physics Phenomena on Housing Architecture in Kampung Naga. IOP Conference Series: Materials Science and Engineering, 288(012044). https://doi.org/10.1088/1757-899X/288/1/012044

Parwati, N. N., Sudiarta, I. G. P., Mariawan, I. M., \& Widiana, I. W. (2018). Local WisdomOriented Problem-Solving Learning Model to Improve Mathematical Problem -Solving Ability. Journal of Technology and Science Education, 8(4), 310-320.

Permatasari, I., \& Hakam, K. A. (2018). The Development of Character Education Based on Sundanese Local Wisdom. IOP Conference Series: Earth and Environmental Science, 145(012124), 1-5. https://doi.org/10.1088/1755-1315/145/1/012124

Pornpimon, C., Wallapha, A., \& Prayuth, C. (2014). Strategy Challenges the Local Wisdom Applications Sustainability in Schools. Procedia - Social and Behavioral Sciences, 112(Iceepsy 2013), 626-634. https://doi.org/10.1016/j.sbspro.2014.01.1210

Putri, D. C., Munandar, A., \& Supriatno, B. (2019). The implementation of indigenous people local wisdom lekuk 50 tumbi in managing agriculture and lakes as biological learning sources. In Journal of Physics: Conference Series (Vol. 1157, pp. 1-5). IOP Publishing. https://doi.org/10.1088/1742-6596/1157/2/022095

Putri, D. P. (2018). Potential threats on pottery as local wisdom in Sitiwinangun Cirebon district. Journal of Physics: Conference Series, 1013(012166). https://doi.org/10.1088/1742-6596/1013/1/012166

Schiefer, D., Mollering, A., Daniel, E., Benish-weisman, M., \& Boehnke, K. (2010). Special issue article Cultural values and outgroup negativity: A cross-cultural analysis of early and late adolescents. European Journal of Social Psychology, 40(January), 635-651. https://doi.org/10.1002/ejsp

Setiawan, B., Innatesari, D. K., Sabtiawan, W. B., \& Sudarmin. (2017). The Development of Local Wisdom-Based Natural Science Module to Improve Science Literation of Students. Jurnal Pendidikan IPA Indonesia, 6(1), 49-54. https://doi.org/10.15294/jpii.v6i1.9595

Shidiq, A. S. (2016). Pembelajaran Sains Kimia Berbasis Etnosains Untuk Meningkatkan Minat Dan Prestasi Belajar Siswa. In Seminar Nasional Kimia dan Pendidikan Kimia VIII (pp. 227-236). Surakarta: Program Studi Pendidikan FKIP UNS.

Suastra, I. W., Jatmiko, B., Ristiati, N. P., \& Yasmini, L. P. B. (2017). Developing Characters Based on Local Wisdom Of Bali In Teaching Physics In Senior High School. Jurnal Pendidikan IPA Indonesia, 6(2), 306-312. https://doi.org/10.15294/jpii.v6i2.10681

Sukmawati, Fuad, M., \& Munaris. (2014). Pepaccur pada masyarakat lampung pepadun dan kelayakannya sebagai materi pembelajaran. J-Simbol (Bahasa, Sastra Dan Pembelajarannya), 2(1), 1-9.

Sunjaya, I., \& Fatimah, I. S. (2017). Redesign of Denggung Park as Sleman Urban Park based on Local Wisdom in Yogyakarta. IOP Conference Series: Earth and Environmental Science, 91(012036), 1-6. https://doi.org/10.1088/1755-1315/91/1/012036

Surtikanti, H. K., Syulasmi, A., \& Ramdhani, N. (2017). Traditional Knowledge of Local Wisdom of Ammatoa Kajang Tribe ( South Sulawesi) about Environmental Conservation. Journal of Physics: Conference Series, 895(012122). https://doi.org/10.1088/1742-6596/895/1/012122

Sutrimah, Winarni, R., Wardani, N. E., \& Ngadiso. (2019). Evaluating the Use of Modern Indonesian Literary History Textbook ( Poetry in East Java ) in Teaching Literary History Course. International Journal of Instruction, 12(3), 1-16.

Taylor, R. T. (2015). Using Literacy Leadership to Improve the Achievement of Struggling Students. Middle School Journal, 36(1), 26-31. https://doi.org/10.1080/00940771.2004.11461461

Udin, G., Zuber, A., \& Demartoto, A. (2018). Karawitan Learning Ethnopedagogy as a Medium 
of Creating Adiluhung Character in Students. International Journal of Multicultural and Multireligious Understanding, 5(3), 295-317.

Vauclair, C., \& Fischer, R. (2011). Do cultural values predict individuals ' moral attitudes ? A cross-cultural multilevel approach. European Journal of Social Psychology, 657(January), 645-657.

Vitasurya, V. R. (2016). Local Wisdom for Sustainable Development of Rural Tourism , Case on Kalibiru and Lopati Village , Province of Daerah Istimewa Yogyakarta. Procedia Social and Behavioral Sciences, 216(October 2015), 97-108. https://doi.org/10.1016/j.sbspro.2015.12.014

Wolosky, S. (2001). The Art of Poetry: How to read a poetry. New York: Oxford University Press.

Yeh, C., Carter, R. T., \& Pieterse, A. L. (2004). Cultural Values and Racial Identity Attitudes Among Asian American Students: An Exploratory Investigation. Counseling and Values, 48(January), 82-94.

Yufiarti, Rivai, R. K., \& Pratiwi, A. P. (2018). Development of Adiwiyata Curriculum Model Based on Local Wisdom. AIP Conference Proceedings, 2019(030012). https://doi.org/10.1063/1.5061865

Yuliana, Sriyati, S., \& Sanjaya, Y. (2017). Local Wisdom of Ngata Toro Community in Utilizing Forest Resources as a Learning Source of Biology. AIP Conference Proceedings, 1868(100007). https://doi.org/10.1063/1.4995217 